\title{
A Company Takes Human Resource as Basic Core Competition Formation
}

\author{
Yanyan Zang \\ School of Economics, Tianjin Polytechnic University, Tianjin 300384, China \\ Tel: 86-22-83956944 E-mail: zangyanyan@hotmail.com
}

\begin{abstract}
A Company is to provide telecommunications, internet billing platform and supporting services technology companies. As a knowledge-intensive small and medium-sized enterprise, human resources is the company's core competitiveness, companies continue the "people-oriented" core values, and human resources to a strategic height. This is the company survival and development of important support for the company's success is based on human resources management. A company's operating and development, utilization of human resources and other management knowledge, analysis of Company A in the management of the problem still exists, make a few constructive comments.
\end{abstract}

Keywords: Core competitiveness, Human resources management, Strategy

A company is to provide telecommunications, internet billing platform and supporting services technology companies. Group was established in 1994, Xi' an, the major business communications industries and technological products and services. 1995 Group formal involvement of Internet technology and investment fields and in 2005 introduced millions of Internet users-level billing platform. A company has a complete legal protection system, has made China's online games, ecommerce, electronic publishing, video, animation, production and distribution of books, IDC, and other formal license / permit. The company has a strong management team capacity, leading from different countries work together to build related industries from the elite for the construction of a vast number of Internet users both international trends and local characteristics of integrated services platform, advanced management methods, and strong technical force and the company has consistently uphold " people-oriented "concept of enterprise development should be relative, co-leading the rapid development of the company. Based on network technology is rising today, to look at the development of digital lifestyle unlimited future, Company A "for users with the most secure, high-speed transactions, entertainment, interactive platform for cooperation" as its mission, and continuously recruit outstanding talent, and seeking enterprises to be more long-term development.

\section{A Corporation based on human resources core competitive ability analysis}

According to Company A of industry characteristics, we can analyze, and the small and medium enterprise is a high-tech enterprise. Such enterprises already in the present-day society in a certain size, because of its mastery of more advanced technology, in comparison to the leading position, the value created by the generally much higher than other enterprises can create value, usually, such enterprises have the following characteristics:

First, the enterprise produces the product technology content high, the intangible asset is big. Performance for management service in high-tech and product research development compared to significant, research and development expense and technical personnel's investment quantity big, in the product materiality, the material cost occupies the product price the proportion to be very small.

Second, high input of. Small and medium-sized high-tech enterprises, not only in its pioneering stage must have substantial capital investment, but must also enter after a long period of substantial additional funds injected. Through scientific and technological achievements, industrial innovation generally has to go through research and development, pilot and the industrialization of three stages. All these business activities with the traditional enterprise production and business activities vary in enterprise development to a certain stage requires a lot of manpower, material resources and financial resources.

Third, the high-risk nature. Small and medium-sized high-tech enterprises in the initial stages of their venture, due to new technologies and new products by the process of development in the socio-economic operations, scientific and technological progress, and other factors, immature technology and people's understanding and mastering it is a process, so at this stage, there is a big investment and enterprise, technical personnel lack of experience, product performance instability, market uncertainty and other risks.

A Company is the basic features, but also in the industry has done quite well in the enterprise. Although the small scale 
enterprises, but its sound human resources management Company A is the development of core strength. The reason why the business is the core competitiveness of human resources management, mainly because the majority of its staff for the knowledge-based software development talent, we all know that the software industry is of great mobility, the status quo in this industry, retain talent, and rational human resource management has become the public Division managers of the major work. Using statistical analysis tool SPSS to human resources to core competitive ability whether has the influence relativity to carry on the analysis, obtains the result, like Table 1.

Table 1. A company human resources and core competitiveness correlation analysis

\begin{tabular}{|c|c|c|c|c|c|}
\hline \multicolumn{3}{|c|}{ Control Variables } & $\begin{array}{l}\text { Managers } \\
\text { ovaluation }\end{array}$ & $\begin{array}{c}\text { Staff } \\
\text { assessment }\end{array}$ & $\begin{array}{c}\text { Core } \\
\text { nonpetitivenoss }\end{array}$ \\
\hline \multirow[t]{3}{*}{-none-a } & Managers evaluation & $\begin{array}{l}\text { Correlation } \\
\text { Significance (2-tailed) } \\
\text { df }\end{array}$ & $\begin{array}{r}1.000 \\
0\end{array}$ & $\begin{array}{r}.758 \\
.007 \\
9\end{array}$ & $\begin{array}{r}.755 \\
.007 \\
9\end{array}$ \\
\hline & Staff assessment & $\begin{array}{l}\text { Correlation } \\
\text { Significance (2-tailed) } \\
\text { df }\end{array}$ & $\begin{array}{r}.758 \\
.007 \\
9\end{array}$ & 1.000 & $\begin{array}{r}.289 \\
.388 \\
9\end{array}$ \\
\hline & Core competitiveness & $\begin{array}{l}\text { Correlation } \\
\text { Significance (2-tailed) } \\
\text { df }\end{array}$ & $\begin{array}{r}755 \\
.007 \\
9\end{array}$ & $\begin{array}{r}.289 \\
.388 \\
9\end{array}$ & $\begin{array}{r}1.000 \\
0\end{array}$ \\
\hline \multirow{2}{*}{\multicolumn{2}{|c|}{$\begin{array}{l}\text { Core competitiveness } \\
\qquad \text { Managers evaluation }\end{array}$}} & $\begin{array}{l}\text { Correlation } \\
\text { Significance (2-tailed) } \\
\text { df }\end{array}$ & 1.000 & $\begin{array}{r}.859 \\
.001 \\
8\end{array}$ & \\
\hline & & $\begin{array}{l}\text { Correlation } \\
\text { Significance (2-tailed) } \\
\text { df }\end{array}$ & $\begin{array}{r}.859 \\
.001 \\
8\end{array}$ & $\begin{array}{r}1.000 \\
0\end{array}$ & \\
\hline
\end{tabular}

a. Cells contain zero-order (Pearson) correlations.

Through the above analysis, it is clear that enterprise managers and employees of enterprises of the state of human resources management and evaluation of the core competitiveness of enterprises are being related. In other words, human resources can be used as a company's core competitiveness.

\section{A company in the human resources management and improving the existing problems}

Through previous analysis we can see that, although the company in the human resources management has some advantages, but, in its course of development, will inevitably produce various problems, the simple summary of view, there are mainly the following three points:

(1) The training of A Company no effective implementation.

(2) A Company lack of an effective incentive mechanism.

(3) A Company no systematic assessment of the performance of the system.

According to the above key issues, A Company combination of practical self-starting from the fierce competition in the market can survive, and the enterprises and better development, and enhance their core competitiveness, and actively seek to improve the program.

Firstly, suitable improvement training plan and effective implementation In the training program, the Human Resources Department in the relevant departments, according to the needs of staff and corporate development goals, jointly developed training programs, after consultation with staff on the revised staff satisfactory in the majority of cases during the implementation. When the training must be teamwork and broaden the curriculum, and this may increase the cohesion among employees, after training for feedback, staff training requirements after their feelings and experiences, not necessarily to staff on the paper, and basically take the easy way higher-level talks, but accept Master listen to the leadership forum to talk about the contents of each record to a comprehensive understanding of the staff.

Secondly, establish a scientific, rational and effective incentive mechanism China's accession to the WTO, the domestic and foreign markets competitive pressures intensify, the domestic human resources costs are much lower relative abroad, foreign investment into China, the talent will vigorously promote the localization strategy, which has high professional standards and wealth of experience of management and technical personnel will inevitably become large companies at home and abroad by the main playing recruitment goals. Therefore, Company A should be formed to retain talented people for the purpose of reasonable incentive mechanism to avoid the loss of business talent. Under normal circumstances, the incentive for enterprise staff and the spirit of no more than two substances, or people in the current labor means survival of the stage, the wage is still motivate staff playing the heavy way. Thus a scientific and rational mechanism for determining performance 
appraisal is incentive to play the basic platform. Assessment criteria in determining the extent possible should be quantified and scientific and rational assessment criteria established between the various weights at the same time, in determining the content of indicators to consider the actual characteristics of the establishment of targeted and effective management in line with the requirements of the enterprise's own index system.

The incentives have many theories, from the level of early demand theory, X Theory, $\mathrm{Y}$ theory to the three kinds of needs of the modern theory, the theory of Goal Setting, expectations theory, the theory fair, comprehensive various theories, common management practice mode nothing more than material incentives and non-material incentives Modern human resources management practice experience and research show that modern management staff are involved in the demands and wishes to provide every opportunity to create and allowing workers to participate in the management of the initiative is to mobilize them an effective way.

People have all sorts of needs, and create appropriate conditions for the non-material, but also an important attract talent of more tools in the work of the people are met is an effective method. According to the quality of its talent and experience with the actual situation within enterprises, in accordance with the objectives of corporate strategy, personnel set up to the challenging task or posts to enable it to be at work in the development of space, not only to meet the talent of self-satisfied, self-fulfillment needs, but also makes people at work have been tempered, in turn, is conducive to the development of enterprises. Enterprises should develop a good competition for talent, adopting the practice of open competition for posts; In order to avoid drastic changes in organizational contusion staff enthusiasm, can also take existing operators to once again venture to develop new projects and new markets, and enable the introduction of new personnel management original industry solution. The Director-General would like to give opportunities to the Director-General to the post, to stem the possible status. In addition, through to the original operator conferred with aides and assistants to real power, the exercise of specific management functions, the original operators from the major guiding role of the consultant or the new replacing the old method.

At the same time, we should pay attention to the importance of encouraging corporate culture; Consideration paid leave by the active role; Skills training will be as the most basic of all the staff of the enterprise, essential requirements, training qualifications as a means of encouraging results to the excellent performance evaluation staff tilt; Focus on the staff level industry development, increasing the temptation to channel technical expertise; handle through competition, leading the work of selecting cadres.

In summary, I believe enterprises by improving performance and incentive mechanism can continuously improve their core competitiveness, in addition, it is worth mentioning that competitiveness lies in innovation, and innovation is the core competitiveness of nurturing a fundamental way. In order to attach importance to the role of enterprises as the core, all types of innovative management practices. "Humanistic Management" and "Center of the" corresponding to the management concept, which calls for understanding, and respect for people and give full play to people's initiative and enthusiasm. Improve the quality of enterprise employees, the most fundamental thing is to constantly strengthen study and learningoriented enterprises to constantly enrich the actual content, in the staff strengthen the concept of lifelong learning, and create a team-learning environment, and encouraging employees to study and adapt to the market competition, adapt to the development needs of the business professional knowledge, enhance workers adapt to a competitive environment, the ability of competent different positions, raising the ideological and moral quality workers and the scientific, cultural, and technological quality, to enhance their core competitiveness and enterprise reform and development, and for the staff to join the comprehensive construction of a well-off society spiritual motivation and intellectual support for ideological security.

\section{References}

C., K., Prahalad \& Gary, Hamel. (1990). The Core Competence of the Corporation [J]. Harvard Business Review 5-6, P79-91.

Li , Xiangyang. (2004). Human resources management and the competitiveness of enterprises [J]. Human resource management and development. 1:30-33.

Wu, Tianzu \& Zou, Gang. (2001). On the enterprises core competitiveness enhancement and development [J]. China's soft science.

Yong, Yan. (1999). Abroad core competitiveness with the theory of Enlightenment [J]. Economics dynamic. 